\title{
Sharing My Story: Representing Social Work at the UN and Select Local Human Rights Activism
}

\author{
Joseph Wronka ${ }^{1}$
}

Published online: 17 March 2016

(C) Springer International Publishing 2016

\begin{abstract}
The author shares primarily select experiences having represented social work at the UN in Geneva from 2006 to the present time. Taking the adage to "think globally and act locally," seriously, he also shares local human rights activism as Town Representative for Amherst, MA. Engaging in what can be called a "phenomenological reduction," he places these experiences in context, by the urging primarily of students, by sharing with the reader an experiential journey, recounting his burgeoning interests in human rights as a teen at the Catholic Worker in New York City; his experiences in Eurasia and in Alaska; his connections with the International Fourth World and The Indigenous Peoples Coalition among others; and most recently his research and experiences as a Fulbrighter in Pakistan. He also shares some of his field work recounting observations and conversations with governmental and nongovernmental representatives in Geneva, and for sometime, previously, at the UN in New York. He shares select portions of most recent policy oral statements given at the 30th session of the Human Rights Council (HRC) in September 2015 on, the Universal Periodic Review (UPR), the Report of the USA to the UPR process, the world drug abuse problem, and the rights of peasants, and finally, a written statement on eradicating extreme poverty before the 24th session of the HRC in September 2013. Before concluding, he mentions in its entirety Warrant Article 28 "Creating a Human Rights Culture" passed almost unanimously before Amherst Town Meeting
\end{abstract}

Representative to the United Nations in Geneva for the International Association of Schools of Social Work (IASSW)

Joseph Wronka

josephwronka@gmail.com

1 School of Social Work, Springfield College, 145 Island Pond Road, Springfield, MA 01109, USA in May, 2015. He concludes with suggestions for human rights activism, like cultivating human rights as a way of life and appealing to the human condition, which moves towards altruism in times of urgency.

Keywords United Nations · IASSW · Social Justice · Human Rights Council · Human Rights Culture · Indigenous · Peasants · Universal Periodic Review · Phenomenology · World Drug Problem

From 2006 to the present time, I have represented social work before the UN Human Rights Council (HRC), newly formed that year, in Geneva. Students and colleagues often ask how I got there, so let me first share my story. Having a background in phenomenology, I feel after all that all research and social action has an experiential dimension, akin to what Merleau-Ponty (1967) called the "phenomenological reduction." Thus, it is important to get one's story out there. I have never done that before in the context of human rights and am honored to share some of my story, a kind of memoir, upon basically students' urgings, in this first issue of the Journal of Human Rights and Social Work, without a doubt a breakthrough in the field of social work, but also, relevant to other helping and health professions broadly defined, including, but not limited to medicine, public health, psychology, nursing, law, and philosophy. Social work, anyway, and ultimately, is interdisciplinary and should we be truly "in the world" and in contact with "brute reality," (Merleau-Ponty 1967) it becomes necessary to adopt approaches that truly transcend the encapsulation of one's own discipline.

Then, I would like to share select observations, activities, and interventions at the UN, primarily in Geneva, including, but not limited to interventions, both oral and written, submitted to the HRC, and activities at so-called side events there. Always cognizant of the adage to think globally and act 
locally, I also want to share some of my involvement in local human rights activism. Finally, I will offer suggestions for future work that will help move towards a "Human Rights Culture," a "lived awareness" in our minds and hearts and dragged into our everyday lives (Creating a human rights culture 2015, p. 1), which is what I think it is all about.

Before continuing, let me first thank the International Association of Schools of Social Work (IASSW) for having appointed me as a representative and independent expert in Geneva, for their faith and confidence in me as I attempted to rubberstamp and further social work values, a profession which after all, as the International Federation of Social Work has stated is "a human rights profession, having as its basic tenet the intrinsic value of every human being" (UN, 1994, p. 3).

\section{My Story}

I recall the first time ever hearing about human rights was when as a 16-year-old teen, I frequented Friday night meetings of the Catholic Worker then on Chrystie Street in the Bowery section of Manhattan, known for its poverty and what that often entailed there, like homelessness, hunger, alcoholism, and a sense of despair in general. Occasionally, I would make special trips to eat at their soup kitchen with those living there, society basically viewing and calling them "Bowery Bums," which I as a young teen recalled finding offensive. It was at those gatherings, that I met a Roger LaPorte, who later self-immolated himself before the UN in protest of the Vietnam War. I was absolutely shocked! Soon, thereafter, I met Dorothy Day, the founder of the Catholic Worker Movement, recently lauded by Pope Francis for her "passion for justice" before the US Congress on September 24, 2015. She was obviously upset and told me "Hopefully, something good will come of it."

Later, even at that young age I become more and more involved with the anti-war movement. I interviewed a David Miller, reportedly the first draft card burner in the U.S., who was hiding in the attic of the Catholic Worker from the FBI. Needless to say, my high school paper refused to publish the interview! Then, some of us would gather, talk about going to Washington D.C. to protest and chant as loudly as possible "LBJ, LBJ, how many kids can you kill today?" My point in relating those formative experiences is that during that time, I often heard the word "human rights" with vague references of their denial to the poor, the hungry, children, and the victims of war, US soldiers certainly, but also all the people of South and North Vietnam. Words like "imperialism," "capitalism," and "colonialism" were also part of the equation, heard by me certainly, but vaguely understood at that time. All that piqued my interest.

During that time, I also saw Martin Luther King's Civil Rights March in Washington, DC, on television, only to find out in my adulthood that it was actually called a "March for
Jobs and Freedom," a name more aligned with the UN Charter which commits nation states to full employment. The zeitgeist of the time was to see him, Fidel Castro, and Nikita Khrushchev as "commies" which, earlier as a child, I myself had fallen for hook, line, and sinker, going around the neighborhood with my superman cape and plastic sword with which I would swagger and say "Die King; die Fidel; die Khrushchev!" But when I heard King's speech, listening to his dream, the table of brotherhood, and going to mountaintop, I could not believe it!

Fast track to my college days, I would go on occasion to the $\mathrm{UN}$, simply to hang out at their bookstore and read up about this vague notion of human rights, that I heard earlier at the Catholic Worker, ideals, which King somehow cemented. For sometime, I carried a copy of the Universal Declaration of Human Rights around with me, talking with others about it, wondering why it was barely mentioned in my classes. At 19, I took a summer off to travel and hitchhike around Europe, which I did from London to Izmir, Turkey and back again. An extremely impressionable experience was when standing on a hill in Izmir, Turkey, as far as my eye could see, I saw families living and begging on blankets. One woman, with her child crying, went to the edge of the blanket and begged for a few coins to buy water for him or her. Still crying and exasperated, she was fortunate enough to have another water seller, crunch down and give him water gratis. Not far away was a European style café, patrons drinking Pernod and coca-cola (costing literally 1000 times more than the water) totally oblivious, it appeared, to the extreme poverty and anguish around them. Did those profits go back to Atlanta, the birthplace of Coke, I wondered. If so, can not the world find a better way to equitably distribute its wealth? The words, capitalism, imperialism, and colonialism began to have a clearer and deeper meaning.

For sometime in my graduate school days, I did some work on the phenomenology of the street musician, myself playing accordion in the streets there, during my "bohemian" days (if they were ever over) at the University of Nice, France. I found it rather impressive that many students, social activists, and faculty in Europe, always spoke highly of the work of the UN and were aware of the Universal Declaration of Human Rights, totally different from my experiences in the US. Around that time also, when teaching in Georgia, then called West Georgia College in the 1970s and then at the University of Alaska in the 1980s, students would be totally shocked that, though the US was a leader in the Universal Declaration's formation, that it did not implement core principles, particularly those of economic, social, and cultural rights, like health care, security in old age, special protections for children, and adequate meaningful and gainful employment. They all wanted to do something. This human rights stuff, I thought, was a winner.

So, I volunteered in the mid 1980 s to be a Group Coordinator for the Fairbanks Chapter of Amnesty 
International. A great group, certainly, I thought, but severely limiting in that it tended to have a rather narrow focus at that time on releasing political prisoners, and eradicating torture and the death penalty. Where was the advocacy for the economic, social, and cultural rights in the Declaration? I asked around from human rights "elites" in Juneau and New York City, only to be told that Amnesty felt that it could not do everything, so it decided, rather arbitrarily, on a rather narrow focus. One of these days, I thought, I would set up my own human rights organization with the entire body of rights of the Universal Declaration as its focus.

Later, in the late 1980s, early 1990s, I was very fortunate to have studied with Dr. David Gil of Brandeis University, Heller School for Social Policy and Management, who later became co-chair of the American Socialist Party (1995-1999) and received the Lifetime Achievement Award in Social Work (2006). He had Amnesty International stickers all over his office. I told him that I felt that group did worthwhile stuff, but was limited in its scope and showed him the Universal Declaration of Human Rights. A person of his stature, perhaps the world's authority on violence against children and author of Violence Against Children (1970) and a book that I began to hold in high esteem, Unraveling Social Policy (Gil 1990), he told me with utmost humility that he did not realize that the Universal Declaration was so thorough and urged me to do something with it. Later, I took a course on International Human Rights Law from Philip Alston, now UN Special Rapporteur on Extreme Poverty, then at Tufts University, and I was on my way.

I wrote my doctoral dissertation, on the interface between human rights and social policy, which later became a book, whose title aptly describes it: Human Rights and Social Policy in the $21^{\text {st }}$ Century: A History of the Idea of Human Rights and a Comparison of the United Nations Universal Declaration of Human Rights with United States Federal and State Constitutions (1992). What I found very briefly is that an educated layperson's reading of the US constitution does not mention any economic, social, and cultural rights, apart from protection for an author's interests. It is no wonder then that, as presidential hopeful, Bernie Sanders stated, "The top one tenth of 1 percent" of Americans "own almost as much wealth as the bottom 90 percent" (Kertscher 2015, p.1). After that first book was published, David and I worked on the Universal Declaration of Human Rights Project, which, in brief aimed to monitor countries' compliance with the principles of the Universal Declaration.

Then just this year in January, I went to Pakistan as a Fulbrighter, granted a senior specialist award in the discipline of social work with "specialities" in social justice and poverty and "subspecialties" in human rights, psychology, and phenomenology. I did a similar analysis of the Constitution of the Islamic Republic of Pakistan, as it is formally called, and found among things that it states "The State shall secure the well-being of the people... by preventing the concentration of wealth and means of production and distribution in the hands of a few to the detriment of general interest and by ensuring equitable adjustment of rights between employers and employees and landlords and tenants ... [and] eliminate riba [unjust profiteering] as early as possible" (PtII, Ar38,a,e). In Pakistan, the gini coefficient for Pakistan is 30 and for the USA 40.8. That coefficient is an index of social inequality, the greater the number the more inequality (UN Development Report, 2013), indicating here a roughly $33 \%$ greater inequality in the USA than Pakistan. My teenage wonderment crystallized, as an adult, into a dream come true.

Soon after graduating, I was offered a teaching position in the Springfield College, School of Social Work, where I integrated human rights into my policy and research classes and developed a more in depth elective on human rights. I also heard that the Council on Social Work Education was coming out with a new edition of their Encyclopedia of Social Work in 1995, but did not have an entry on human rights. Strange, I thought, considering the International Federation of Social Work's assertion of social work as a human rights profession. I offered to write one, which was accepted. During my early years at Springfield, all the while, serving on the Board for a Coalition for a Strong United Nations, I heard about a group called the International Fourth World Movement, which dedicates itself to the eradication of extreme poverty, the kind of group I had initially envisioned years earlier. It is often referred to simply as ATD Fourth World, "ATD" standing for "All Together in Dignity." What a find, I thought, and began working with them. I had no idea that they were so connected and soon I found myself invited as one of 500 activists globally to the $50^{\text {th }}$ Anniversary of the UN endorsement of the Universal Declaration of Human Rights in 1998 at the Palais de Chaillot in Paris hob knobbing with extremely dedicated risk taking human rights activists, many of whom were nuns and priests, reminiscent of my Catholic Worker days. There were also the social activists Angela Davis and Dennis Brutus, along with Nobel laureates like the Dalai Lama, Adolfo Perez Esquival, Jose Ramos Horta, Rigoberta Menchu. I was lucky.

I kept in contact with ATD Fourth World, when their Representative to the UN in Geneva, Xavier Verzat and Elaine Mouravief-Apostol, then the Main Representative to the UN in Geneva for the International Federation of Social Work (IFSW) asked if I would be interested in going there, primarily because they were lobbying to have governments endorse the First Draft of the Guiding Principles to Eradicate Extreme Poverty. They told me that "seeing a new kid on the block" viewing extreme poverty as a human rights violation would help give fodder to some of their efforts. After working with them for a couple of years, I wondered why IASSW did not have a very strong and active presence there and asked representatives in the US, particularly Dr.'s Jane Wetzel in New York and Lynne Healy in Connecticut if they would 
consider me to represent IASSW. They agreed. The board endorsed me. So, here I am today.

\section{Being at the UN}

I prefer to say "being," rather than "working" at the UN, which in this case is primarily its headquarters in Geneva, though I will begin with some of my experiences in New York. I say "being" also because I was certainly not a formal employee there. But, over the years traveling globally and, for some time even, doing a stint as Vice President of the World Citizen Foundation, I am convinced that formal venues of working, whether as a social activist, administrator, even clinician are only part of the story. The real issue is to learn how to be with others informally, in the everyday life, in a dignified way, not treating them as charity cases that need to be helped, viewing and relating with others as possibilities, not actualities, seeing them fully with the intrinsic value of being human, beyond appearances and our own stereotypes. I am not saying I am perfect at that myself, but at least, I think that I try. I must say that I had learned a lot of that by working in an Inupiat community in the Arctic, slowly having come to the realization that Inupiat culture had an extremely high tolerance for eccentricity, accepting and forgiving others to extents that I just did not see in traditional white culture. In that regard, they are still a model for me.

To this day even, I have been pleased to engage in coalition building with the Indigenous Peoples Coalition in Geneva, often thinking wistfully of my earlier days in Alaska. In other words, the indigenous people, there, saw beyond roles in the traditional workplace and related as person to person, rather holistically in ways that seemed pre-existential and phenomenological, in a Heideggerian sense (recall that Heidegger (1959) laid out a strong philosophical foundation for qualitative research) as "beings-in-the-world." Thus, when I was at the UN, my purpose was not to see what I did there as a job, but, rather to be attentive to my and others' entire being in the world, that would enhance social interactions in ways that could be productive to move towards the development of a human rights culture that I have written about on my website (mentioned above) and my latest book, Human Rights and Social Justice: Social Action and Service for the Helping and Health Professions (2008, forthcoming). That book, if I may, is scheduled to appear in its second edition sometime this summer and, among other things, will elaborate on some of the experiences described below.

I think then that in social work, it is safe to say that life is the profession. Whereas it may be a more common practice to find a profession in life, should we be true to the calling of social work as a human rights profession, we have an obligation as social workers and helping and health professionals to make human rights a way of life, not only in formal venues, but, informal ones, true to the vision of Eleanor Roosevelt, as we all know a pivotal and early pioneer in the human rights movement who said that human rights begin "In small places, close to home.... they are the world of the individual person; the neighborhood he lives in; the school or college he attends; the factory, farm or office where he works. Such are the places where every man, woman and child seeks equal justice, equal opportunity, equal dignity without discrimination" (Human Rights for All 2015, p. 1). Thus, during my years at the UN, I tried to be in the world in a certain way that transcended formal definitions of work and adhered to human rights principles as a way of life, to treat others with dignity and nondiscrimination, among other things.

\section{In New York and Geneva: Select Observations and Interventions}

It is not within the scope of this essay to delineate all the differences and subtleties between the work of the U.N. in New York and Geneva. But, by and large, it could be said that major human rights initiatives begin in Geneva as articulated by the Human Rights Council (HRC) there. It was formed in 2006, a progeny of the Human Rights Commission founded in 1946, which appeared to have become too politicized. It consists of 47 member states, elected by majority of the General Assembly and meets there three times annually, in September, March, and June. At the $30^{\text {th }}$ session of the HRC, for instance, a study The Impact of the World Drug Problem on the Enjoyment of Human Rights was presented for general debate (see below my statement before the HRC) before governments and non-governmental actors. In 2016, there will be a U.N. General Assembly Special Session (UNGASS) pertaining to that document which will pass resolutions favorable and/or opposed to that document, which, hopefully state actors will implement.

Roughly, furthermore, the HRC in Geneva delineates standards setting as enunciated in guiding principles, declarations, and conventions following the Universal Declaration of Human Rights, originally articulated by the Human Rights Commission. It also consists of various implementation measures, like the Universal Periodic Review (UPR) (see below) and human rights committee monitoring mechanisms of conventions primarily, which have a stronger juridical force. The UPR, initiated in 2007, whose deliberations can be found on the Internet, appears the most promising at the moment. Every four years, a country comes before the HRC to engage in a creative dialogue with the council to implement human rights standards. Presently, there are nine major conventions pertaining to civil and political rights, economic and social rights, women, racial discrimination, torture, children, immigrants, persons with disabilities, and enforced disappearances. Taken altogether, the Universal Declaration, the guiding 
principles, etc., and monitoring mechanisms have been referred to as the Human Rights Triptych. (For a further discussion of this Triptych, see Wronka (2008, forthcoming; 2012).

But, prior to the formation of the HRC in 2006, some monitoring committees met in New York, a vignette of my experiences discussed below.

My first major connection with the UN, therefore, was in 1995 when the US was before the human rights monitoring committee for the International Convention on Civil and Political Rights (ICCPR), one of the nine major human rights conventions, mentioned earlier. I sat arbitrarily next to a person who introduced himself as "Sly, a student of Malcolm." This place is cool, I thought. But all of us human rights advocates in the audience were wondering why there were no cameras at such a historic event! The committee brought up one concern after another, like the death penalty, hate speech, excessive gun deaths as a violation of the right to life, lack of inclusion of the citizens of the District of Columbia in policy making, and police brutality. But, they were careful to stress positive aspects too, like the increase of minorities in job positions, and the US Bill of Rights being a beacon of hope for humanity.

I wondered why there was no mention of childhood poverty, recalling that the Children's Defense Fund had stated that in the U.S., one out of three children in the US go to bed hungry each night or at risk of being hungry (cited in Wronka 1992). The moderator then told all NGO's to leave the room, the majority of us, realizing that at times, it is necessary to break all the rules as long as no one gets hurt, simply stayed put, facial expressions very slightly reminiscent of my Vietnam War days that "Hell no, we won't go." Later, I went up to a member of the committee asking him why the US or the monitoring committee neither mentioned childhood poverty. Later, over a few beers, with NGO's and the monitoring committee, I brought that up again. They really seemed to listen. The following day, they brought it up to the US, whose weak response essentially was that is the way it is. Members of the committee told me also that they were upset, when I brought that up. Now, I am aware of an Arab proverb: "If a person does a good deed and tells someone about it, it is as if it had never been done." My point here is simply to tell my story and to point out that taking risks and informal venues can have long-lasting policy implications. Indeed, in Carter's Talking Peace (1993), he spoke about interpersonal connections that generally opposing forces had made, while simply hanging out at a barbecue, resulting in the Camp David Accords. So, maybe, it is ok to fly under the radar at times, let alone, be attentive to casual opportunities for socially just actions.

On the other hand, there definitely needs to be formal, officially recognized ways of doing things, such as the submitting of oral and written statements, sometimes called "interventions" in international circles, before fora that have the possibility of making an impact on social policies, in order that they be consistent with fundamental human rights principles. Informal venues are good, but, at worse, they can be excuses by governments for doing nothing. I recall for example, a side event in Geneva on the exploitation of natural resources and wildlife in French Equatorial New Guinea. After an hour and twenty minutes presenting their case, at a one and one half hour forum, the official representative from France entered the room apologizing for being late. "What!" Said the members, primarily indigenous, of the panel. "We can't get an audience with the French government in our own country. We travel 9000 miles and you give us only ten minutes!" After the French representative thanked them for bringing attention to the abuses there, making pledges to do something about them (usual fanfare in international circles), the moderator said that the meeting had to end, concluding with the words "I encourage you to continue this discussion over a few beers." A true story! Certainly, governments that make up the UN can do better than that! Trying to resolve centuries of imperialism over a few beers... really! Good grief! or should I say Mon Dieu! that French equivalent of those words of exasperation by the cartoon character Charlie Brown of the acclaimed Peanuts

Before sharing portions of select policy statements submitted to Human Rights Council meetings over the years, I would first like to share some general impressions. In fact, some of things I heard there were pretty unbelievable in my view and largely, if not, totally unheard of in the U.S. While the U.S. press lauded President Obama in the Ukraine, for example, I would hear there his actions being equivalent to the Nazi invasion of Poland. President Putin would not be bullied. I heard about waters in Iraq being polluted with plutonium and remnants of cluster and barrel bombs being used in the War in Iraq, such that many women were afraid of getting pregnant, as children were born with two heads and four legs. I also heard about Frontex, that was supposedly a border protection patrol for the European Union (EU). But, they would intercept refugees from Africa, strip search them, and send them back into the Mediterranean in their underwear with no food or water. Should they be found with a dead corpse on board, that corpse would go out again with them, that story corroborated by an article on the Internet. Representatives of both governmental and NGO's from the Third World, still a relatively respectable appellation, often felt that many of the rights discussed before the HRC in the main Hall, Room XX, at the Palais des Nations, like the need for gay and lesbian marriages, the release of political prisoners, the elimination of torture and the death penalty, were important issues certainly, but in their words were "miniscule" when thinking about the legacies in general of colonial exploitation by the U.S. and the European Union (EU) for centuries. Anyway, many governments would talk about how they had policies that eradicated torture, only to have a citizen from that country sitting next to me, tell me "That was a lie. My brother was tortured by a 
government official." When I told her to relate to that representative her story, she replied "What? And have another family member tortured?"

I recall once a rather fruitful conversation with the representative from Sudan, who admitted to me that what was going on there was horrendous. But he had questioned why there was not a similar outcry with the atrocities in the Congo. He felt that Europe, predominately Christian, just did not want to lambaste another predominately Christian, in this case, Catholic, country, the Congo. Muslim against Muslim, he said, was a rich narrative to the Western Press, which he compared to Julius Streicher, publisher of a vitriolic anti-Semitic newspaper, Der Sturmer. Both whipped up hate, but now most recently towards Muslims.

In Geneva, there is a place where people congregate called Bar Serpent, rooms constructed in the shape of a snake, but I noticed that almost always it was filled with NGO's, interaction there, and in other venues, rather limited with governmental representatives. To be fair, NGO's can still speak with them, but they must be approached as they go into and/or out of the main hall, as there appear mixed policies about NGO's approaching them in the room.

\section{Select Oral and Written Interventions Submitted to the HRC}

OK. Les voila (here they are), excerpts of select oral statements before the HRC, mentioned in their entirely in my forthcoming Human Rights and Social Justice. While I have given many over the years, I decided for the sake of expediency and their newness to mention four submitted before the HRC $30^{\text {th }}$ session in September/October 2015. To place these in context, please note that at the HRC meetings, they have various agenda items, such as responded to below, as pertaining to the efficacy of the UPR, the report of the U.S.A. regarding the UPR, the world drug problem, and declaration on the rights of peasants. States are given five minutes to respond; NGO's are given two. NGO's are also invited to submit a written statement on themes pertaining to a particular session of the HRC, which I did in September 2013. To be sure, the documents that the HRC generates are almost literally "lessons," the meaning of that word from the Latin, documentum, i.e., lesson. I see them as very important, literally, lessons that the world must learn to move towards a socially just world, constructed from the pillars of human rights. Ultimately, knowledge of these documents is more important than understanding the intricacy of the UN system.

Given that time and resources are severely limited, my primary aim, in essence, was to relate before the HRC a persuasive policy brief. To be sure, to point out the lack of human rights principles, which actually mirror millennia of spiritual teachings, in state and supranational institutional structures, is persuasive enough. Persuasive also are the words of respected historical and contemporary authorities, like Crazy Horse, Eleanor Roosevelt, Jane Addams, President Obama, and Pope Francis. Also, I have always felt that the human condition was moved towards altruism in times of crises, so I tried to appeal to images, metaphors, and numbers that related to the suffering of many of the world's population and expressing the urgency of global crises. As appropriate, I also thought it important to debunk American exceptionalism, that is, the USA is the best country in the world. To be sure, the USA has its strengths, President Roosevelt's Four Freedoms to have freedom of speech, religion and freedom from want and fear a major thrust leading to the formation of the U.N. and later his wife, Eleanor, becoming chairperson of the drafting committee for the U.N. Universal Declaration of Human Rights. But, still, we have ratified only three of the major human rights conventions. Indeed, should we believe in President Eisenhower's assertion that every bomb made is theft from the poor, the USA, since it manufacturers a little over $50 \%$ of the world's armaments, could be considered the greatest thief! Below are select excerpts, which demonstrate those considerations.

1) As pertaining to the efficacy of the Universal Periodic Review

It has been said that the Universal Periodic Review is a way for countries to "air out their dirty laundry." The International Association of Schools of Social Work rejects that metaphor. Rather, it sees the UPR process as akin to the Spirit of Crazy Horse, named after that great indigenous and spiritual leader of the Lakota, which has been described as "peace, humility, and everlasting love." Reminded of the words of Gandhi "honest disagreement is often a good sign of progress," the creative dialogue that the UPR fosters can move us towards peace. Humility, an awareness that other countries, as well as our own, are neither perfect, nor exceptional, can help us move towards a spirit of mutual reciprocity to build on strengths and work on weaknesses as often urged by Jane Addams, Nobel Prize winner, sometimes called the mother of social work. And everlasting love, an ethic found in some of the world's great religions and largely mirrored in human rights documents to love your neighbor as yourself in the Christian gospel; to do to your brother (or sister) only what you would like to be done to yourself in the Holy Koran, Sura; and to do unto others, for all the rest is commentary as asserted in the Jewish Torah.

We also urge that supranational organizations, such as the World Bank, the International Monetary Fund, and the World Trade Organization receive the same inquiry as nation states, reminding this August body that some corporations have GNP's greater than some countries and 
that the word privatization comes from the Latin privare meaning "to steal" and structural adjustment policies may be suspect.

Our impressions are also that these reports need more emphasis upon eradicating structural violence. We ask nations to heed the words of Pope Francis that "human rights are not only violated by terrorism, repression or assassination, but also by unfair economic structures that create huge inequalities"... and that "unbridled capitalism is the dung of the devil," thus implementing Article 28 of the Universal Declaration, which calls for a socially just order.

2) On the Universal Periodic Review outcomes for the United States of America:

The International Association of Schools of Social Work welcomes the report of the United States of America and especially appreciates its humility when it says, "While recognizing there is more work to be done, we are constantly striving to create a fairer and more just society."

But the USA indicated that "human rights are embedded in our constitution." Whereas it is true that civil and political rights are stated forthrightly there, indeed, the monitoring committee for the ICCPR referred to the Bill of Rights as a beacon of hope for humanity. Yet, the US constitution barely mentions economic, social, cultural, and solidarity rights and states which are to act as "laboratories for democracy... to extend rights not found in the federal constitution," as stated by former Supreme Court Justice Louis Brandeis substantively mention only the right to education. But, where are rights to health care, security in old age, special protections for the family, reasonable wages, rest and leisure, and self-determination? Presently, it takes by and large three incomes to support a family and parents rarely have time to spend with their children.

We ask the USA to take more seriously the words of former President Eisenhower who said that every bomb made is theft from the poor and question why the USA spends roughly $49 \%$ of global expenditures on armaments. Also, why is it that reportedly 2500 individuals who committed crimes when children are in prison for life without the possibility of parole, which is close to ten times more than all other countries combined that implement such a policy. We also express sadness, yes sadness, that President Obama said that it was "shameful" that his country has not ratified the Rights of Child, but has not followed through. President Obama, please ratify that important document.

3) Response to the UN study on the impact of the world drug problem on the enjoyment of human rights.

The International Association of Schools of Social Work applauds the recent study on the impact of the world drug problem on the enjoyment of human rights and urges all governments to distribute it widely in their policy making bodies. Also, we find it written very well in non-elitist terminology, but in educated layperson's language as advocated by Eleanor Roosevelt for human rights documents to be written and in this second decade of human rights education, urge that it be incorporated in secondary, yes, high school, post-secondary, and professional curricula for robust debate. And we thank this council for eliciting NGO input.

We especially like its commitment to ethnic and cultural diversity with its support, as appropriate, for the use of coca leaves among indigenous people in Bolivia and the use of peyote in the Native American Church in the USA. We are reminded of the failure of the "Just say No" policy in some indigenous communities, where avoiding conflict is a value. But what was effective was when teenagers would hand over letters to those pressuring them, from their elders urging them not to use. Such instances are consistent with the human right to self-determination, that terminology absent in that report.

We also view substance abuse as a function of isolation and trauma. We view the war on drugs as an absurd metaphor. If we need a war on anything, it is on isolation and trauma. It may be no coincidence that heroin use appears to have grown worldwide, consistent with studies that have indicated increased loneliness over the last few decades.

4) As pertaining to the new declaration on the rights of peasants

The International Association of Schools of Social Work strongly supports the declaration on the rights of peasants and unequivocally endorses statements in state constitutions that reserve places in their legislative bodies for peasants, or for that matter, those in extreme poverty, a sizeable number of whom are peasants. A case in point is the Constitution of the Islamic Republic of Pakistan, where I recently returned as a Fulbrighter, which reserves places in their legislative bodies for peasants. There, according to the UN data, the ratio of wealth between the highest $10 \%$ and the lowest $10 \%$ is less than one half than that of some countries, like the United States, which does not have such a provision. In the USA, roughly $0.1 \%$ have almost as much wealth as the bottom $90 \%$ according to Bernie Sanders, presidential hopeful (Gorman and Kertscher 2015). True, the United States has enacted an affirmative action policy for its legislative bodies, based on race, minimally implemented it seems, but that country and others need now, the time is now, to have affirmative action programs based also on class, making up for centuries of discrimination against those who lived in extreme poverty and also rural areas, that is, peasants, generally far away from urban centers, where 
policies are often formulated, legislated, implemented, and evaluated.

The most recent written statement submitted to the HRC on the promotion and protection of all human rights, civil, political, economic, social, and cultural rights, including the right to development was in September 2013 before the $24^{\text {th }}$ session. Below are excerpts:

IASSW feels that extreme poverty "shocks the conscience of humanity" as asserted in the Preamble in the Universal Declaration of Human Rights and is a gross and massive violation of human rights. Select data are that roughly 1.4 billion people globally go to bed hungry each night, some from developed countries. More than $80 \%$ of the world's population lives in countries where income differentials are widening. Indeed, the wealthiest nation on earth, the USA, has the widest gap between rich and poor of any industrialized nation. The poorest 40 percent of the world's population accounts for $5 \%$ of the world's income; the richest $20 \%$ accounts for three quarters of world income. According to UNICEF, 22,000 children die each day due to poverty who "die quietly in some of the poorest villages on earth, far removed from the scrutiny and the conscience of the world. Being meek and weak in life makes these dying multitudes even more invisible in death." Roughly $28 \%$ of children in developing countries, most notably South Asia and sub-Saharan Africa, are underweight or stunted seriously questioning whether the Millennium Development Goals target of having the proportion of underweight children will be missed by 30 million children. Nearly a billion living today cannot read a book or sign their names. Infectious diseases continue the blight of the poor with an estimated 40 million living with HIV/AIDS and 500 million cases of malaria.

Access to clean and potable water also affects roughly half of humanity; 1.1 billion in developing countries have inadequate access to water, and roughly 3 billion lack basic sanitation, the majority of those living on less than $\$ 2$ per day. The nearly two billion in developing countries who do have access to water within one kilometer of their house consume 20 liters per day, whereas those in developed countries like the United Kingdom consume an average of 150 liters daily and in the USA consume the highest average of 600 liters per day. There are indeed massive economic wastes associated with water and sanitation deficit pertaining to health spending, productivity loss, and labor diversions. Sub-Sahara Africa, for instance, loses about $5 \%$ of their GDP in that regard or $\$ 28.4$ billion annually. There are approximately 500 billionaires, that is, $0.000008 \%$ of the world's population who were worth an estimated $\$ 3.5$ trillion; there are 2.4 billion people in lowincome countries that account for $\$ 1.6$ trillion of the GDP; $51 \%$ of the world's 100 hundred wealthiest bodies are corporations. For every \$1 spent in aid in developing countries, \$25 is spent on debt repayment. Just $1 \%$ of what the world spent on weapons could effectively be used to put every child into school, a scenario which has never happened. (Data for the above is from http://www.globalissues.org/article/26/povertyfacts-and-stats) But it is not just statistical data that recall to mind "the world's most pitiless killer" as asserted by UNICEF. It is also the "lived suffering" of those in extreme poverty. They may be under constant threat of losing their homes; unsure where their next meal is coming from; lying homeless, barely clothed in frigid weather; constantly dealing with health problems throughout their lives that could have been prevented; and/or are victims of environmental catastrophe.

A case in point is the voice of a 15 -year-old Michelle Collins who during Hurricane Katrina stated: "While walking to the Superdome, there was water almost all the way up to our stomachs. We saw a lot of people just dying... it was terrible. It was like a hospital mixed with hungry people... people getting raped and hurt. We were sleeping on the floor and it was wet... I didn't know where my mom was. Not until eight months or a year later, I was able to communicate with her." (ATD Fourth World Movement, 2012, Not Meant to Live Like This, pp. xiv.) As a way out of this global pogrom, IASSW asks all governments in concert with all structures of civil society, such as NGO's, businesses, financial, and educational institutions three to endorse and implement the final draft of the guiding principles on extreme poverty and human rights, submitted by the Special Rapporteur on Extreme Poverty and Human Rights, Magdalena Sepúlveda-Carmona, on July 18, 2012 before the $21^{\text {st }}$ session of the Human Rights Council, under agenda item three on the protection of all human rights: civil and political; economic, social, and cultural; and the right to development.

\section{Select Local Human Rights Activism}

On the local front, there was House Bill 850 in 2000 which was to examine Massachusetts's laws and policies in light of internationally recognized human rights principles (Wronka 2008). Although it failed, via skillful community organizing with social justice groups in Western Massachusetts as well as some of my students, I think it got together roughly 30 organizations in this state along the spectrum from liberal to conservative. A rather important creative dialogue ensued to implement human rights principles, possibly playing a role in having Massachusetts become the first state to endorse gay and lesbian marriages and health care as a human right.

But, let me once again share a most recent initiative in the town that I live in, Amherst, Massachusetts, which was "Warrant Article 28, Towards a Human Rights Culture," passed in May 2015, at Town Meeting almost unanimously:

WHEREAS, Article VI, Clause 2 of the US Constitution asserts: "All treaties made or shall be made... shall become 
the Supreme Law of the Land and the judges in every state shall be bound thereby;"

And WHEREAS, the UN Charter, the Universal Declaration of Human Rights, as the authoritative statement of customary international law, and major UN human rights conventions have the status of international treaty, NOW THEREFORE BE IT RESOLVED: The town of Amherst calls upon all federal, state, and municipal legislative, executive, and judicial bodies to sign, ratify, and implement such conventions as they presently exist and evolve. This warrant article will be deposited with U.S. Senator Elizabeth Warren; President Obama; Samantha Power, U.S. Ambassador to the UN; Senator Bob Corker, Chair of the Senate Foreign Relations Committee; Charlie Baker, Governor of Massachusetts, and other policy makers as appropriate in order that they take positive steps in that direction. Doing so would be a step towards creating a human rights culture among the general populace, a "lived awareness" of human rights principles in our minds and hearts and carried into our everyday lives, ultimately resulting in socially just policies, where every person, everywhere can live with dignity and have their human rights realized.

Below are excerpts of my presentation in support of that article:

In brief, that warrant article asks the town of Amherst to call upon key policy makers, including but not limited to, President Obama, U.S. Senator Elizabeth Warren of Massachusetts, and Ambassador to the U.N. Samantha Power, to sign, ratify, and implement U.N. human rights conventions as they presently exist and as they evolve. Sadly, the United States has a rather poor record here having ratified only three of the nine major conventions, which can be found in the PowerPoints posted on the Internet, that is, those pertaining to racism, torture, and civil and political rights. A major case in point is US failure to ratify the Rights of Children, which the President had said is "shameful." He needs a nudge. Pakistan and Austria, where I went as a Fulbrighter, have ratified eight of the nine conventions, and many other countries have similar records.

An impetus for this warrant article is in part to assist in regaining US leadership in the realm of global ethics, as after all, President Roosevelt's Four Freedoms speech in 1941, immortalized in the paintings of Western MA's Norman Rockwell, called upon governments to guarantee freedom of expression, the right to worship, and freedoms from want and fear. These principles were major pillars, which formed the United Nations.

Another impetus is that this article serves as a kind of educative function in this World's Third Decade of Human Rights Education. Article 6 of the US Constitution states for instance: "All treaties made shall become the Supreme Law of the Land." All UN conventions have the status of treaty. Ramsey Clarke, former US Attorney General, has stated that lack of knowledge of that fact represents a failure of the legal system. It is important also to know about the Human Rights Triptych, with the Universal Declaration of Human Rights at the center, flanked by the conventions following it on the right and implementation measures like human rights reports on the left, like UN concerns about racism in the US, like racial profiling, an increasing militarized approach to immigration law enforcement, and Hispanic children particularly facing harsh conditions in forced agricultural labor.

Finally, all human rights instruments, as the former Pope John Paul II stated as pertaining to the Universal Declaration of Human Rights, need to be "lived in letter and in spirit." Thus, human dignity, non-discrimination, an ethic of human rights for every person, everywhere, to mention a few principles, need to be "lived" and in our minds and hearts and dragged into our everyday lives, often referred to as a human rights culture.

We may not see the results of this warrant article now, but should we believe in intergenerational solidarity; eventually, our children and their children might be able to reap the fruits of a human rights culture. Thank you.

\section{Where Do We Go from Here?}

Recalling my experiences in my formative years as a teenager, I would first like to emphasize the importance of human rights education from the grammar school to high school levels. Curricula can simply mention to students, for example, the principles of the Universal Declaration of Human Rights, asking how it can be implemented. Although I did not mention here in depth the Human Rights Triptych, consisting of the Universal Declaration at the center; guiding principles, declarations, and conventions on the left panel; and implementation mechanisms on the right (see Wronka 2008, 2012, 2013, 2014), it is important as I have argued before the HRC to have all that UN machinery understandable to children. Research consistently demonstrates that once values are inculcated, it is almost impossible to change them. It is important that our youth need to learn about such principles, collectively understood as creating a human rights culture, to emphasize a lived awareness of human rights principles in our minds and hearts and dragged into our everyday lives. Ultimately, human rights is a way of life, as consistently argued by Shulamit Koenig, founding president of the Peoples Movement for Human Rights Learning (www.pdhre.org), and we must begin at an early age. That is key and perhaps the most fundamental to constructing a socially just world, with human rights at its core.

At the post-secondary level and at professional schools, it is imperative that human rights principles be endorsed and integrated into their curriculum. This is not just for social work and the helping and health professions per se, but also, at least, 
its "cousins," peace studies, world citizenship, international and domestic law, public policy, actually any profession that wants to improve the quality of life, which, ultimately, should include all. Principles, such as human dignity, non-discrimination, alignment with a socially just international order, must be integrated and be in accordance of internationally accepted human rights standards (For further examples, see Wronka 2008, 2012, 2013, 2014; Healy and Link 2012; Hokenstad et al. 2013; Libal et al. 2014). And we all ought to know in educated layperson's terms about Article 6, The Supremacy Clause of the US Constitution, which asserts, "all treaties [human rights conventions]... shall become law of the land."

In this Third Phase of the World Program for Human Rights Education (2015-2019), with its emphasis upon using the media to enhance the creation of a human rights culture, it is important to spread the word, creatively, by artistic venues, talk shows, public service announcements (psa's), videos (amateur or otherwise) that speak to such principles, if not their violation. In all modesty, I have done a number of psa's and have begun a human rights show, which can be accessed by going to: https:// www.amherstmedia.org/search/node/Wronka.

All the helping and health professions, ultimately all professions I think need to begin social movements to place on job descriptions, that one's responsibilities are also "to engage in social action activities to create a socially just world" or simply, "to create a human rights culture." As a college professor, though I have on occasion used my own funds, yet, always mindful as my prime responsibility to my students, I have, nevertheless, been fortunate to get course release time, sabbaticals, travel grants, and an occasional "gig" abroad not far from Geneva, to do my human rights work. I am especially grateful for Springfield College and the School of Social Work for their support in that regard. During the years, I have seen government representatives exit from Hotel Palais Wilson, where rooms are $\$ 500$ per night. NGO reps, including myself, would go to couchsurfers.com, Air bnb.com, and/or stay at a friends or friend of a friend's place. Before the HRC, I have asked governments to have better funding for NGO's. That has not materialized, but we must keep on trying to find the economic means that we can to wage peace, rather than war, phenomenally more expensive, estimated at two trillion dollars per year, in contrast to the UN budget of roughly two billion. Certainly, should at least the social work and the helping and health professions take seriously multi-pronged interventions to eradicate social malaises and promote well-being from the meta-macro to the meta-micro (Wronka 2008), funding is imperative. To be sure, the further up one goes to put out the fire on the burning ship (macro), rather than just pull bodies out of the water (micro), more time, effort, and money is necessary. The results may not immediately be seen, but in the long run will have a more long-lasting effect.

We also need to strengthen the UN's capacity, let alone the regional organizations like the African Union, the Organization of American States, and the European Charter (Wronka 2008), to influence policy. There needs to be a coordinating mechanism between international organizations and domestic policy to ensure that our international commitments, the most obvious one being the Universal Declaration of Human Rights, are implemented in domestic settings. House Bill 850 and the Amherst Warrant Article 28 on the Creation of a Human Rights Culture may serve as a couple of examples.

In one submission before the HRC and at a side event, I mentioned that the human condition is moved towards altruism in times of emergency. I recall, when giving the Dr. Ambedkar lectures (2002) at the National Institute of Social Work and Social Sciences (NISWASS) in Bhubaneswar, India, soon after that terrible earthquake in Gujarat, that The Hind $u$ was exhilarant that there were no caste distinctions in helping others. The Brahmin priestly caste, it said, without hesitation did everything they could help other groups, like the Dalits, previously referred to pejoratively as "The Untouchables." Recall all those that put their lives on the line to help survivors of 9/11. What I am saying is that we need to have social movements to develop a global sense of urgency around issues of the time that could easily be considered catastrophic, like environmental degradation, climate change, and extreme poverty, all interrelated.

Whatever we do, as tempting as it might be to stoop to another's level, our actions must be non-violent. Mindful of the words of Martin Luther King, Jr. that "we must not seek to defeat or humiliate the enemy, but to win his friendship and understanding" (King 2015, p. 1), our aims must always be "friendship and tolerance" as asserted in Article 27 of the Universal Declaration of Human Rights. Mindful also of the words of Confucius that "the wise person is one who keeps on trying, even though he [or she] knows it is futile," we must keep on trying and never give up!

\section{References}

Carter, J., \& Reynolds, S. (1993). Talking peace: a vision for the next generation. New York: Dutton Children's Books.

Creating a human rights culture (2015). Website for Dr. Joseph Wronka. Retrieved November 26, 2015 at: www.humanrightsculture.org

Gil, D. (1970). Violence against children. Cambridge: Harvard University Press.

Gil, D. (1990). Unraveling social policy (4th ed.). Rochester, VT: Schenkman.

Gorman, S. \& Kertscher, T. (2015). Bernie Sanders says top.1\% have almost as much wealth as the bottom $90 \%$. Retrieved on January 1 , 2015 at: http://www.politifact.com/virginia/statements/2015/sep/21/ bernie-s/bernie-sanders-says-top-01-us-have-almost-much-wea/

Healy, L., \& Link, R. (Eds.). (2012). Handbook of international social work: human rights, development, and the global profession. New York: Oxford University Press.

Heidegger, M. (1959). An introduction to metaphysics. New Haven, CT: Yale University Press. 
Hokenstad, T., Healy, L., \& Segal, U. (Eds.). (2013). Teaching human rights: curriculum resources for social workers. Alexandria: Council on Social Work Education.

Human rights for all. (2015). Retrieved November 25, 2015 at: http:// www.un.org/en/globalissues/briefingpapers/humanrights/quotes. shtml

Kertscher, T. (2015). Bernie Sanders in Madison. Retrieved November 27, 2015 at: http://www.politifact.com/wisconsin/statements/2015/ jul/29/bernie-s/bernie-sanders-madison-claims-top-01-americanshav/

King, M. (2015). Loving your enemies. Retrieved November 26, 2015 at: $\mathrm{http}: / /$ www.salsa.net/peace/conv/8weekconv4-2.html

Libal, K., Berthold, S., Thomas, R., \& Healy, L. (Eds.). (2014). Advancing human rights in social work education. Alexandria, VA: Council on Social Work Education.

Merleau-Ponty, M. (1967). The phenomenology of perception. (C. Smith, Trans.). New York: Routledge and Kegan Paul.

U.N. Development Report. (2013). Retrieved January 2, 2016 at: http:// hdr.undp.org/en/content/income-gini-coefficient

United Nations. (1994). Human rights and social work: a manual for schools of social work and the social work profession. New York: Author.
Wronka, J. (1992). Human rights and social policy in the 21st century: a history of the idea of human rights and comparison of the United Nations Universal Declaration of Human Rights with United States federal and state constitutions (revth ed.). Lanham, MD: University Press of America.

Wronka, J. (2002). The Dr. Ambedkar lectures on the theme creating a human rights culture. Bhubaneswar, India: National Institute of Social Work and Social Sciences (NISWASS).

Wronka, J. (2008). Human rights and social justice: social action and service for the helping and health professions. Los Angeles: Sage. Note: Second edition scheduled for 2016.

Wronka, J. (2012). Overview of human rights: the UN conventions and machinery. In L. Healy \& R. Link (Eds.), Handbook of international social work: human rights, development, and the global profession (pp. 439-446). New York: Oxford University Press.

Wronka, J. (2013). An overview of human rights. In T. Hokenstad, L. Healy, \& U. Segal (Eds.), Teaching human rights: curriculum resources for social workers (pp. 3-20). Alexandria, VA: Council on Social Work Education (CSWE) Press.

Wronka, J. (2014). Human rights as the bedrock of social justice: implications for advanced generalist practice. In K. Libal, S. Berthold, R. Thomas, \& L. Healy (Eds.), Advancing human rights in social work education (pp. 19-38). Alexandria, VA: CSWE Press. 